\title{
TEKNOLOGI PROSES EKSTRAKSI TOKOFEROL DARI RUMPUT LAUT SEBAGAI SUMBER VITAMIN E PADA SABUN MANDI
}

\section{(EXTRACTION PROCESS TECHNOLOGY TOCOPHEROL FROM SEAWEED AS A SOURCE OF VITAMIN E AT BATH SOAP)}

\author{
Yuni Adiningsih \\ Balai Riset dan Standardisasi Industri Samarinda \\ Jl. Harmonika No. 3 Samarinda \\ y-adinings@kemenperind.go.id \\ Naskah diterima tanggal 5 Pebruari 2013, disetujui tanggal 14 Mei 2013
}

\begin{abstract}
ABSTRAK
Propinsi Kalimantan Timur mengembangkan budidaya perikanan khususnya rumput laut, terutama di daerah Bontang, Kabupaten Kutai Timur, Berau serta Nunukan. Potensi rumput laut tersebut cukup besar yaitu sekitar 170.000 ton/tahun (Dinas Perikanan 2012). Rumput laut selain memiliki klorofil atau pigmen warna yang lain juga mengandung vitamin A dan vitamin E (Sunarto, 2003). Vitamin E mencegah lipofuscin, lemak yang teroksidasi pemicu proses penuaan kulit secara dini. Tujuan dari penelitian ini adalah untuk mengetahui metode ekstraksi rumput laut jenis Euchema Cotonii sehingga diperoleh ekstrak rumput laut dengan kandungan vitamin E dalam bentuk Tokoferol. Selanjutnya ekstrak rumput laut tersebut ditambahkan sebagai additive ke dalam sabun sebanyak $2 \%$. Teknik ekstraksi yang digunakan adalah metode kristalisasi dingin dengan pelarut metanol. Hasil ekstrak rumput laut diuji menggunakan metode HPLC dan diperoleh kandungan tokoferol 0.17 - $1.14 \mathrm{IU}$, asam lemak bebas 3,54\%-4.42\% dan bilangan peroksida $4.05 \%$ 4.15\%. Penambahan ekstrak rumput laut sebagai sumber tokoferol tidak mempengaruhi mutu sabun yang dihasilkan yaitu sesuai standar SNI 06-3532-1994 (SNI Sabun mandi)
\end{abstract}

Kata kunci : rumput laut, Euchema Cotonii, kristalisasi dingin, tokoferol, sabun mandi

\section{ABSTRACT}

East Kalimantan province has developed seaweed aquaculture in particular, especially in the area of Bontang, East Kutai, Berau and Nunakan. The seaweed potential is quite large at around 170,000 tonnes / year (Department of Fisheries 2012). Like land plants in general, seaweed also has chlorophyll or other pigment colors. In addition, seaweed contains vitamin $A$ and vitamin $E$ (Sunarto, 2003). Vitamin $E$ prevents lipofuscin, oxidized fats trigger premature aging of the skin. The purpose of this study was to determine the types of seaweed extraction method to obtain Euchema cotonii seaweed extract with vitamin $E$ in the form of Tocopherol. Furthermore seaweed extract is added as an additive into the soap as much as $2 \%$. Extraction technique used is the method of cold crystallization with methanol. Seaweed extract were tested using HPLC method and obtained tocopherol content 0.17 to $1.14 \mathrm{IU}$, free fatty acids $3.54 \%-4.42 \%$, peroxide $4.05 \%-4.15 \%$. The addition of seaweed extract as a source of tocopherols did not affect the quality of the soap produced according to standard SNI 06-3532-1994 (SNI soap)

Keywords : Euchema cotonii, seaweed, cold crystallization, tocopherol, bath soap 


\section{PENDAHULUAN}

$\mathrm{P}$ ropinsi Kalimantan Timur telah mengembangkan budidaya perikanan khususnya rumput laut, terutama di daerah Bontang, Kabupaten Kutai Timur serta kabupaten Berau. Berdasarkan data Dinas Perikanan Propinsi Kalimantan Timur (2012) jumlah rumput laut sekitar 170.000 ton/tahun. Karena potensi yang cukup besar maka perlu dilakukan pengembangan produk Diversifikasi produk dengan memanfaatkan rumput laut sebagai sumber vitamin $\mathrm{E}$ (tokoferol).

Rumput laut dapat dimanfaatkan sebagai sumber makanan dengan nilai lebih terhadap kesehatan, sebagai makanan fungsional dan dapat digunakan sebagai bahan pembuatan produk biokimia seperti vitamin, karoten, asam lemak tidak jenuh termasuk omega-3. Di samping itu, rumput laut mengandung mineral yang cukup tinggi mengingat habitatnya yang merupakan muara mineral terbesar, karena translokasi mineral dari daratan ke lautan akibat proses dari pencucian (leaching) dan aliran hidrologis. Seperti layaknya tanaman darat pada umumnya, rumput laut juga memiliki klorofil atau pigmen warna yang lain. Selain itu, rumput laut mengandung vitamin $A$ dan vitamin E sebagai tokoferol (Sunarto, 2003).

Mengingat potensi yang besar baik dari jumlah maupun manfaatnya, maka rumput laut patut dikembangkan sebagai sumber vitamin $E$ alami. Pemisahan (ekstraksi) vitamin $\mathrm{E}$ dari fraksi tidak tersabunkan perlu dikaji agar diperoleh cara yang tepat dan efisien. Teknik yang telah dikembangkan pada proses ekstraksi vitamin $E$ dari minyak nabati meliputi metilasi kimia, distilasi molekuler, dan fraksinasi etanol (Nagao et al., 2004), adsorpsi dengan adsorben (Chu et al., 2004; Chu et al, 2005), ekstraksi dengan cairan superkritis (Ibanez et al., 2002), enzimatis dan distilasi molekuler (Watanabe et al., 2004), serta kombinasi distilasi, saponifikasi, dan winterisasi (Lewis, 2001). Teknik-teknik tersebut rumit dan umumnya melibatkan suhu tinggi. Isomer vitamin $E$ sangat peka terhadap suhu. cahaya dan oksigen. Oleh karena itu perlu dikembangkan cara ekstrak tokoferol yang sederhana dan aplikatif menggunakan suhu rendah. Keunggulan kristalisasi pelarut adalah penggunaan suhu rendah dan mudah diaplikasikan dengan peralatan sederhana.

Hasil ekstrak rumput laut diaplikasikan ke dalam sabun dari minyak sawit untuk mendapatkan sabun dengan nilai lebih yaitu mengandung tokoferol. Sabun adalah bahan yang digunakan untuk mencuci dan mengemulsi, terdiri dari dua komponen utama yaitu asam lemak dengan rantai karbon C16 dan sodium atau potasium (Ophardt, 2003). Sabun merupakan pembersih yang dibuat dengan reaksi kimia antara kalium atau natrium dengan asam lemak dari minyak nabati atau lemak hewani (BSN, 1994). Sabun yang dibuat dengan $\mathrm{NaOH}$ dikenal dengan sabun keras (hard soap), sedangkan sabun yang dibuat dengan $\mathrm{KOH}$ dikenal dengan sabun lunak (soft soap). Sabun dibuat dengan dua cara yaitu proses saponifikasi dan proses netralisasi minyak. Proses saponifikasi minyak akan memperoleh produk sampingan yaitu gliserol, sedangkan proses netralisasi tidak akan memperoleh gliserol. Proses saponifikasi terjadi karena reaksi antara trigliserida dengan alkali, sedangkan proses netralisasi terjadi karena reaksi asam lemak bebas dengan alkali (Ophardt, 2003). Tujuan penelitian ini adalah mendapatkan teknologi proses ekstraksi rumput laut sebagai sumber tokoferol .

\section{METODE PENELITIAN}

\section{Bahan dan Alat}

Rumput laut jenis Euchema Cottoni yang diperoleh dari petani Bontang, methanol dari PT Kaltim Methanol Indonesia, $\mathrm{KOH}$, etanol, Natrium bisulfate, heksan, gliserin, minyak sawit, asam askorbat, $\mathrm{NaOH}$, asam stearat, kertas saring whatman ukuran 42 .

Peralatan yang digunakan terdiri dari blender, botol kaca, rotary evaporator, pemanas, shaker, gelas ukur, timbangan, HPLC. 


\section{Metode}

Penelitian dilaksanakan dengan variabel pelarut untuk proses maserasi dan variabel penambahan pelarut pada tahap penyabunan.

\section{Maserasi}

Pada proses ini rumput laut sebanyak $500 \mathrm{gr}$ yang sudah dihaluskan, diekstraksi dengan cara dilakukan perendaman dengan variabel pelarut methanol dan heksan masing masing sebanyak $1000 \mathrm{ml}$ selama 3 hari. Hasil ekstrak disaring dan dimasukan ke dalam erlenmeyer $500 \mathrm{ml}$, lalu diaduk menggunakan spatula sampai larutan berwarna kuning. Perendaman menggunakan heksan tidak dilanjutkan karena rumput laut menjadi menggumpal sehingga tidak diperoleh ekstrak rumput laut.

\section{Penyabunan}

Proses perendaman dengan methanol dilanjutkan dengan proses penyabunan. Dalam hal ini dilakukan variabel penambahan dan tanpa penambahan pelarut. Pelarut yang digunakan dalam proses ini adalah methanol dan aquadest. Proses penyabunan tanpa penambahan pelarut dilakukan dengan tahapan sebagai berikut : sebanyak 250 gram hasil maserasi ditambah etanol $96 \%$ sebanyak $135 \mathrm{ml}, 7,5$ $\mathrm{ml} \mathrm{KOH} 50 \%$ dan asam askorbat 0,75 gram. Campuran tersebut dipanaskan dalam penangas air pada suhu $65^{\circ} \mathrm{C}$ selama 30 menit. Lalu erlenmeyer didinginkan dengan air mengalir, selajutnya dipindahkan kedalam labu pemisah. Hasil ekstraksi dimasukkan dalam wadah gelap dan dilanjutkan proses kristalisasi.

Variabel penelitian dengan penambahan pelarut dilakukan dengan tahapan sebagai berikut : sebanyak 250 gram hasil maserasi ditambah etanol $96 \%$ sebanyak $135 \mathrm{ml}, 7,5 \mathrm{ml} \mathrm{KOH} 50 \%$ dan asam askorbat 0,75 gram. Campuran tersebut dipanaskan dalam penangas air pada suhu $65^{\circ} \mathrm{C}$ selama 30 menit. Lalu erlenmeyer didinginkan dengan air mengalir, selajutnya dipindahkan kedalam labu pemisah. Kemudian dilakukan penambahan pelarut methanol sebanyak $225 \mathrm{ml}$ dan akuades $300 \mathrm{ml}$, dikocok dan disaring dengan menggunakan $\mathrm{Na}_{2} \mathrm{SO}_{4}$. Hasil ekstraksi dimasukkan dalam wadah gelap dan dilanjutkan proses kristalisasi.

\section{Kristalisasi}

Proses kristalisasi berlangsung di dalam lemari pendingin dengan suhu $0^{\circ} \mathrm{C}$ selama 4 hari. Setelah proses kristalisasi disaring dengan kertas saring dalam kondisi suhu dingin dan stabil. Kemudian dilakukan penguapan metanol menggunakan rotary evaporator dengan suhu $50^{\circ} \mathrm{C}$ selama 10 15 menit hingga didapat fraksi kaya tokoferol. Fraksi kaya tokoferol tersebut dianalisis meliputi kadar tokoferol menggunakan HPLC.

\section{Pembuatan Sabun}

Ekstrak rumput laut yang mengandung tokoferol ditambahkan pada sabun. Proses pembuatan sabun dilakukan dengan tahapan sesuai Gambar 1.

I. Tahap pertama

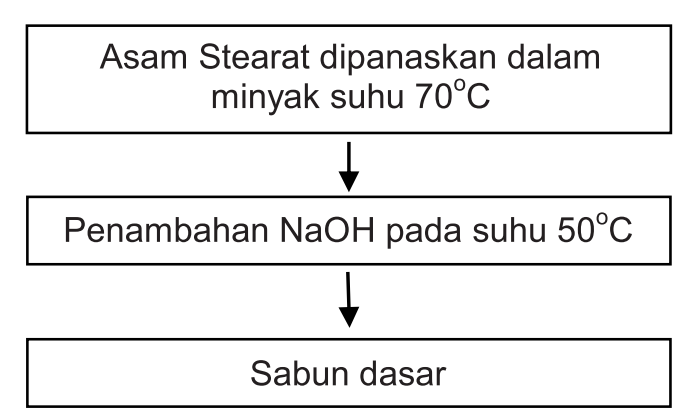

II. Tahap kedua

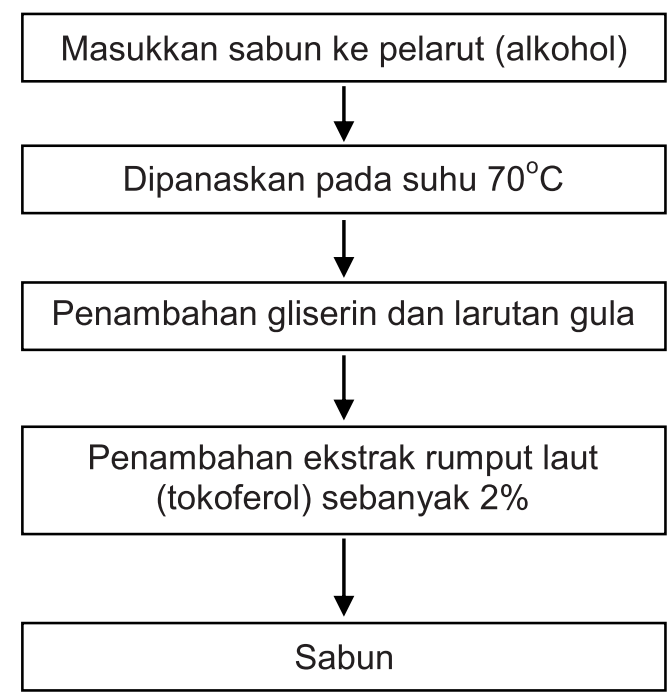

Gambar 1. Proses pembuatan sabun 


\section{HASIL DAN PEMBAHASAN}

Berdasarkan penelitian yang dilakukan, diperoleh hasil pengamatan dan pengujian ekstraksi rumput laut.

\section{Ekstraksi Rumput Laut}

Ekstraksi dilakukan dengan menggunakan metode maserasi dengan variabel pelarut yaitu methanol dan heksan yang merupakan pelarut organik yang dapat digunakan untuk proses ekstraksi. Pemilihan proses ekstraksi dengan metode maserasi sangat menguntungkan karena dengan perendaman sampel tanaman/nabati akan mengakibatkan pemecahan dinding sel dan membran sel akibat perbedaaan tekanan antara di dalam sel dan di luar sel sehingga metabolit sekunder yang ada dalam sitoplasma akan terlarut dalam pelarut organik dan ektraksi senyawa akan sempurna karena dapat diatur lama perendaman yang dilakukan. Maserasi merupakan proses perendaman sampel dengan pelarut organik dengan beberapa kali pengocokan atau pengadukan dalam temperatur ruangan. Pemilihan pelarut dalam proses maserasi akan memberikan efektifitas yang tinggi dalam memperhatikan kelarutan senyawa bahan alam dalam pelarut tersebut. Secara umum, pelarut metanol merupakan pelarut yang paling banyak digunakan dalam proses isolasi senyawa organik bahan alam karena dapat melarutkan golongan metabolit sekunder (Darwis, dalam Fahri, 2010).

Dari hasil penelitian yang dilakukan penggunaan metanol sebagai pelarut dalam proses ekstraksi menggunakan metode maserasi menghasilkan larutan berwarna kuning yang mengindikasikan adanya kandungan zat yang terlarut. Penggunaan heksan sebagai pelarut kurang efektif karena rumput laut menggumpal dan tidak dapat dipisahkan antara larutan dan padatan. Sehingga pelarut yang digunakan untuk tahap selanjutnya menggunakan methanol.

\section{Kandungan Tokoferol}

Perlakuan rumput laut dengan tahapan ekstraksi, penyabunan dan kristalisasi menghasilkan kandungan tokoferol sebagai berikut :

Analisa Kandungan Tokoferol (berdasarkan pengujian dengan metode HPLC).

Dari hasil pengujian pada tabel 1 terlihat bahwa hasil kandungan tokoferol di rumput laut sebesar $0.17 \mathrm{~s} / \mathrm{d} 1.14 \mathrm{IU}$. Hasil pengujian yang dilakukan pada proses penyabunan dengan penambahan pelarut menghasilkan kandungan tokoferol sebesar 0,17 IU. Nilai ini lebih rendah dibanding proses yang dilakukan tanpa penambahan pelarut (methanol dan air) yaitu sebesar 1,14 IU. Penambahan pelarut menyebabkan terjadi proses pengenceran. Rumput laut yang tidak mengalami proses perlakuan ekstraksi, penyabunan dan kristalisasi setelah dilakukan uji kandungan tokoferol menggunakan metode HPLC diperoleh nilai sangat kecil yaitu dibawah 0,02 IU. Ini menunjukan bahwa rumput laut merupakan tanaman laut yang mengandung tokoferol, tetapi untuk mendapatkannya harus melalui teknologi ekstraksi dan kristalisasi

Tabel1. Kandungan Tokoferol dan Ekstrak Rumput Laut.

\begin{tabular}{lc}
\hline Nama Bahan & $\begin{array}{c}\text { Kandungan } \\
\text { Tokoferol (IU) }\end{array}$ \\
\hline Rumput laut & $<0,02$ \\
$\begin{array}{l}\text { Ekstrak tanpa } \\
\text { penambahan pelarut }\end{array}$ & 1.14 \\
$\begin{array}{l}\text { Ekstrak dengan } \\
\text { penambahan pelarut }\end{array}$ & 0.17 \\
\hline
\end{tabular}

Pada tahap kristalisasi, terjadi proses pembentukan kristal komponen-komponen yang tidak larut dalam pelarut dan mempunyai titik beku yang lebih tinggi dari suhu yang digunakan akan membeku dan membentuk kristal. Pelarut berperan penting untuk menurunkan viskositas (Krishnamurthy and Kellens, 1995). Viskositas yang rendah menyebabkan perpindahan massa menjadi mudah sehingga proses kristalisasi bersifat efisien. 
Hal ini akan mempermudah proses separasi komponen yang diinginkan. Jenis pelarut berperan penting pada proses kristalisasi karena pelarutan merupakan faktor penting pada proses kristalisasi. Kelarutan suatu komponen dalam pelarut ditentukan oleh polaritas masing-masing. Diduga ada sedikit perbedaan polaritas dari komponenkomponen yang ada dalam fraksi tidak tersabunkan, termasuk perbedaan polaritas tokoferol dan tokotrienol serta masingmasing isomernya. Oleh karena itu, penentuan jenis pelarut yang tepat penting dilakukan pada proses ekstraksi.

Pada proses kristalisasi, pelarut mempengaruhi kecepatan nukleasi dan morfologi kristal. Teknik ekstraksi pelarut dan kristalisasi memiliki keuntungan yaitu dapat memisahkan tokoferol dari fraksi tidak tersabunkan lainnya berdasarkan titik leleh tokoferol dan tidak menyebabkan oksidasi tokoferol.

Selain dilakukan pengujian untuk kandungan tokoferol, dilakukan pengujian karakteristik ekstrak rumput laut berupa asam lemak bebas dan bilangan peroksida.

Tabel 2. Hasil uji Asam Lemak Bebas dan Bilangan Peroksida Ekstrak Rumput Laut.

\begin{tabular}{lcc}
\hline \multicolumn{1}{c}{$\begin{array}{c}\text { Proses } \\
\text { Ekstraksi }\end{array}$} & $\begin{array}{c}\text { Asam } \\
\text { Lemak } \\
\text { Bebas (\%) }\end{array}$ & $\begin{array}{c}\text { Bilangan } \\
\text { Peroksida } \\
\text { (\%) }\end{array}$ \\
\hline $\begin{array}{l}\text { Tanpa } \\
\text { penambahan } \\
\text { pelarut }\end{array}$ & 4.42 & 4.15 \\
$\begin{array}{l}\text { Penambahan } \\
\text { pelarut }\end{array}$ & 3.54 & 4.05 \\
\hline
\end{tabular}

Kandungan asam lemak bebas hasil ekstraksi rumput laut berkisar antara 3.54\% - $4.42 \%$. Proses ekstraksi secara kristalisasi menunjukan kadar asam lemak bebas yang rendah. Hal ini disebabkan karena semakin rendah suhu kristalisasi berpengaruh terhadap pembentukan kristal asam lemak bebas yang semakin banyak. Kristal tersebut akan terpisah dengan filtrate pada saat penyaringan sehingga menurunkan kadar asam lemak bebas. (Cahyanine, 2008)

Hasil pengujian parameter bilangan peroksida ekstrak rumput laut menunjukan nilai $4.05 \%$ - $4.15 \%$. Bilangan peroksida adalah indeks jumlah lemak atau minyak yang telah mengalami oksidasi. Angka peroksida sangat penting untuk identifikasi tingkat oksidasi minyak. Minyak yang mengandung asam- asam lemak tidak jenuh dapat teroksidasi oleh oksigen yang menghasilkan suatu senyawa peroksida. Dari hasil pengujian ekstrak rumput laut menunjukan angka peroksida yang rendah. Ini disebabkan karena laju pembentukan peroksida baru lebih kecil dibandingkan dengan laju degradasinya menjadi senyawa lain, mengingat kadar peroksida cepat mengalami degradasi dan bereaksi dengan zat lain. Oksidasi lemak oleh oksigen terjadi secara spontan jika bahan berlemak dibiarkan kontak dengan udara, sedangkan kecepatan proses oksidasinya tergantung pada tipe lemak dan kondisi penyimpanan.

\section{Pembuatan Sabun dengan Penambahan Ekstrak Tokoferol}

Pembuatan sabun dengan penambahan tokoferol, diperoleh hasil pengujian pada Tabel 3.

Menurut George dalam Hernani dkk, 2010, Karakteristik sabun yang dihasilkan dipengaruhi oleh distribusi asam lemak yang digunakan. Dalam penelitian ini asam lemak yang digunakan bersumber dari minyak sawit.

Tabel 3. Hasil pengujian mutu sabun

\begin{tabular}{|c|c|c|}
\hline $\begin{array}{c}\text { Parameter } \\
\text { Pengujian } \\
\text { (SNI 06-3532- } \\
\text { 1994) }\end{array}$ & $\begin{array}{c}\text { Sabun } \\
\text { dengan } \\
\text { tokoferol }\end{array}$ & $\begin{array}{c}\text { (SNI 06- } \\
3532- \\
1994)\end{array}$ \\
\hline $\begin{array}{l}\text { Kadar air } \\
\text { Jumlah asam } \\
\text { lemak } \\
\text { Alkali bebas }\end{array}$ & $\begin{array}{l}12.75 \\
72.45\end{array}$ & $\begin{array}{c}\text { Maks } 15 \\
>70\end{array}$ \\
\hline $\begin{array}{l}\text { Dihitung } \\
\text { sebagai } \\
\mathrm{NaOH}\end{array}$ & 0.03 & Maks 0.1 \\
\hline $\begin{array}{l}\text { - } \quad \text { Dihitung } \\
\text { sebagai } \\
\mathrm{KOH}\end{array}$ & 0.05 & Maks 0.14 \\
\hline $\begin{array}{l}\text { Asam lemak } \\
\text { bebas }\end{array}$ & 1.72 & $<2.5$ \\
\hline Minyak mineral & Negative & Negatif \\
\hline
\end{tabular}




\section{Kadar air}

Kadar air merupakan bahan yang menguap pada suhu dan waktu tertentu. Bila dibandingkan dengan standar SNI 063532-1994, kadar air maksimal adalah 15\%, hal ini disebabkan agar sabun yang dihasilkan cukup keras sehingga lebih efisien dalam pemakaian dan sabun tidak mudah larut dalam air. Kadar air akan mempengaruhi kekerasan dari sabun. Dari hasil penelitian sabun yang dibuat masih memenuhi standar yang ditentukan. Banyaknya kandungan air akan berpengaruh terhadap kelarutan sabun. Semakin banyak kandungan air maka sabun akan semakin mudah menyusut pada saat digunakan. (Hernani dkk, 2010).

\section{Jumlah Asam Lemak}

Jumlah asam lemak merupakan jumlah total seluruh asam lemak pada sabun yang telah atau pun yang belum bereaksi dengan alkali (SNI,1994). Sabun yang berkualitas baik mempunyai kandungan total asam lemak minimal $70 \%$, hal ini berarti bahan-bahan yang ditambahkan sebagai bahan pengisi dalam pembuatan sabun kurang dari $30 \%$. Tujuannya untuk meningkatkan efisiensi proses pembersihan kotoran berupa minyak atau lemak pada saat sabun digunakan. Bahan pengisi yang biasa ditambahkan adalah madu, gliserol, waterglass, protein susu dan lain sebagainya. Tujuan penambahan bahan pengisi untuk memberikan bentuk yang kompak dan padat, melembabkan, menambahkan zat gizi yang diperlukan oleh kulit.

\section{Alkali Bebas}

Alkali bebas merupakan alkali dalam sabun yang tidak diikat sebagai

senyawa. Kelebihan alkali bebas dalam sabun tidak boleh lebih dari $0,1 \%$ untuk sabun $\mathrm{Na}$, dan $0,14 \%$ untuk sabun $\mathrm{KOH}$ karena alkali mempunyai sifat yang keras dan menyebabkan iritasi pada kulit. Kelebihan alkali bebas pada sabun dapat disebabkan karena konsentrasi alkali yang pekat atau berlebih pada proses penyabunan. Sabun yang mengandung alkali tinggi biasanya digunakan untuk sabun cuci. Dari hasil uji di atas sabun yang dihasilkan masuk dalam standar SNI.

\section{Asam Lemak Bebas}

Asam lemak bebas merupakan asam lemak pada sabun yang tidak terikat sebagai senyawa natrium atau pun senyawa trigliserida (lemak netral). Tingginya asam lemak bebas pada sabun akan mengurangi daya membersihkan sabun, karena asam lemak bebas merupakan komponen yang tidak diinginkan dalam proses pembersihan. Sabun pada saat digunakan akan menarik komponen asam lemak bebas yang masih terdapat dalam sabun sehingga secara tidak langsung mengurangi kemampuannya untuk membersihkan minyak dari bahan yang berminyak.

\section{Minyak Mineral}

Hasil uji menunjukan bahwa sabun tidak mengandung minyak mineral. Minyak mineral merupakan zat atau bahan tetap sebagai minyak, namun saat penambahan air akan terjadi emulsi antara air dan minyak yang ditandai dengan kekeruhan. Minyak mineral adalah minyak hasil penguraian bahan organik oleh jasad renik yang terjadi berjuta-juta tahun. Minyak mineral sama dengan minyak bumi beserta turunannya. Contoh minyak mineral adalah : bensin, minyak tanah, solar, oli, dan sebagainya. Kekeruhan pada pengujian minyak mineral dapat disebabkan juga oleh molekul hidrokarbon dalam bahan.

Dari parameter pengujian yang dilakukan, penambahan ekstrak tokoferol tidak mempengaruhi mutu sabun mandi sesuai SNI 06-3532-1994, karena penambahan ekstrak hanya dalam jumlah kecil yaitu $2 \%$ dari formula sabun.

\section{KESIMPULAN}

Dari hasil penelitian dan pengujian, dapat diambil kesimpulan bahwa rumput laut jenis Euchema Cottonii mengandung tokoferol yang dapat diambil menggunakan tahapan proses ekstraksi dengan pelarut methanol, penyabunan dan kristalisasi. Kandungan Tokoferol Euchema Cotonii sebesar 0.17 
s/d 1.14 IU, asam lemak bebas 3,54\%$4.42 \%$ dan bilangan peroksida 4.05\%$4.15 \%$. Pembuatan sabun dengan penambahan ekstrak tokoferol dari rumput laut menunjukan produk sabun memenuhi persyaratan SNI 06-3532-1994 untuk parameter kadar air, jumlah asam lemak, alkali bebas dihitung sebagai $\mathrm{NaOH}, \mathrm{KOH}$, asam lemak bebas dan minyak mineral.

\section{DAFTAR PUSTAKA}

Standar Nasional Indonesia (1994) 063532-1994 Sabun Mandi , Jakarta

Cahyanie, 2008, "Fraksi Kaya Tokoferol dari Bekatul Beras dengan Teknik Kristalisasi Pelarut Suhu Rendah", Jurnal Teknologi Pertanian Vol.9 No.3, Universitas Brawijaya, Malang

Chu, B. S., B.S. Baharin, Y.B. Man, and S.Y. Quek. 2004. "Separation of vitamin $\mathrm{E}$ from palm fatty acid distillate using silica: I Equilibrium of batch adsorption". J. Food Eng. 62(1): 97103

Chu, B.S., Y.B. Baharin, Che Man, and S.Y. Quek. 2005. "Comparison of selected adsorbents for adsorption and desorption of vitamin $E$ from palm fatty acid distillate." Journal of Food Lipids

Darwis dalam Fahri, 2010, http://elfahrybima.blogspot.com/2010/ 10/teknik-ekstraksi-senyawaflavonoid-dari.html (diakses tgl 26 Agustus 2011)
Hernani dkk, 2010, "Formula sabun Transparan Anti Jamur dengan Bahan Aktif Ekstrak Lengkuas", Bul Littro Vol. 21 No. 2, Bogor

Ibanez, et al. 2002. Concentration of sterols and tocopherols from olive oil with supercritical carbon dioxide. J. of Am. Oil Chem. Soc. 79: 1255-1260.

Krishnamurthy, R. and M. Kellens. 1995. Fractionation and Winterization. In $\mathrm{Y}$ H.Hui (ed.). Bailey's Industrial Oil and Fat Products. Edible Oil and Fat Products: Processing Technology $.5^{\text {th }}$ ed. Vol. 4. A John Wiley \& Sons, Inc., New York

Lewis, J. 2001. Process for the production of tocotrienol. US Patent 6,838,104

Nagao, et al. 2004. "Recovery of sterol as fatty acid steryl esters from waste material after purification of tocopherols". Lipids 39(8): 784-794

Ophardt, C. E. 2003. Soap. http://elmhurst.edu/chm/vchembook/554soap.html (diakses tanggal 6 Agustus 2011)

Sunarto, 2003, Potensi Nutrisi Rumput Laut, http://www.docstoc.com/ docs/20905224/KI-671NMT 2003/Sunarto-2 (diakses tgl 5 September 2011) 